\title{
Online Business Simulations: Authentic teamwork, learning outcomes and satisfaction
}

Gui Lohmann, Griffith University

Associate Professor in Air Transport and Tourism Management

Griffith Aviation, Griffith University, 170 Kessels Road, Building N25, room 1.18, Nathan, QLD, 4111, Australia

g.lohmann@griffith.edu.au

$+61737354059$

ORCID: 0000-0002-3374-9734

Marlene A. Pratt, Griffith University

Department of Tourism, Sport and Hotel Management, Griffith University, Parklands Drive, Southport QLD 4215

Australia

ORCID: 0000-0003-2138-8246

Pierre Benckendorff, The University of Queensland

UQ Business School, The University of Queensland, St Lucia, QLD, 4072, Australia

ORCID: 0000-0002-2794-8534

Paul Strickland, La Trobe University

La Trobe University, Kingsbury Drive, Bundoora, VIC, 3086, Australia

ORCID: 0000-0002-3298-3967

Paul Reynolds, University of South Australia

Paul A Whitelaw, William Angliss Institute 


\begin{abstract}
Educators have struggled to incorporate authentic team-based learning (TBL) into the business curriculum despite increasing evidence that collaborative learning can enhance learning outcomes. We investigate the use of online business simulations as a platform for fostering authentic TBL for undergraduate and postgraduate business students studying at seven institutions in Australia and Hong Kong. Quantitative analysis of 365 surveys is supported by focus groups with fourteen students. Structural equation modeling (SEM) is used to model the relationships between teamwork, learning outcomes and satisfaction. Qualitative results support the statistical modelling and are presented to add further insights and conceptual richness. The findings support our proposition that online business simulations provide an authentic TBL environment, which contributes to learner satisfaction by supporting the development of management-related learning outcomes through socially constructed meaning. This conceptual contribution highlights further avenues for research and leads to some practical implications for educators using simulation-based pedagogies.
\end{abstract}

Keywords: online business simulation; teamwork; learning outcomes; experience; satisfaction

\title{
Acknowledgements
}

Support for this project has been provided by the Australian Government Office for Learning and Teaching (OLT).

The views in this project/activity do not necessarily reflect the views of the OLT. The project team would like to acknowledge the assistance of Dr Char-Lee McLennan, Dr Jakob Trischler, Wendy London and Lainie Groundwater and the contributions of the Reference Panel consisting of A/Prof Mark Freeman, Prof Janne Liburd, Prof Ulrike Gretzel, Dr Trish Andrews and Dr Sandra Barker. Any errors are the authors' responsibilities. 


\section{Introduction}

The ascendance of neoliberal ideology and the concomitant shifts in education and labor market policies have placed universities under increasing pressure to produce employable graduates (Bridgstock 2009; Giroux 2010). The focus on employability has coincided with a period of rapid growth in both business school enrolments and business degree granting colleges and universities (Pfeffer and Fong 2002). This success has created a number of challenges for business schools. Inevitably larger class sizes have led to reduced levels of interaction and transmissive teaching and assessment approaches that favor knowledge acquisition over the teaching of employability skills (Arias and Walker 2004). Nearly three decades ago, Leavitt (1989, p. 39) lamented that the design of business programs had created "critters with lopsided brains, icy hearts, and shrunken souls." Mintzberg (1996) argued that the typical business school experience was too far removed from the context of management as a practice-based craft. Very little appears to have changed in the intervening years, with Pfeffer and Fong (2002, p. 85) observing that "students learn to talk about business but it is not clear they learn business."

The ability to identify and work towards goals, communicate ideas, identify problems and solutions and make complex decisions are critically important employability skills for business graduates. Despite increasing evidence that these skills can be developed and enhanced through collaborative learning, instructors have struggled to effectively embed meaningful collaborative learning opportunities into the business curriculum (Hansen 2006). While team-based learning and assessment tasks are commonly used in business education, students often respond by dividing the task amongst team members who work independently to complete component parts. This tendency for students to compartmentalize team projects limits opportunities for socially constructed meaning and the development of higher order employability skills such as goal setting, strategic planning and decision making. We address this issue by proposing and testing the argument that online business simulations create opportunities for authentic team-based learning (TBL), which in turn enhances learning outcomes and satisfaction. 
With this in mind, we test the following two propositions: (1) Online business simulations provide an authentic TBL environment that contributes indirectly to learner satisfaction by supporting the development of management-related learning outcomes; and (2) Online business simulations provide an authentic TBL environment that contributes directly to learner satisfaction. In the following section we explore research on teamwork factors that are relevant to the learning outcomes of online business simulations. In doing so, we consider behaviors that influence teamwork performance such as team dedication and interaction. We then review simulation-based learning as a tool for enhancing learning outcomes. Finally, we review the evidence regarding learning outcomes and learner satisfaction with the use of simulation-based pedagogies. This is followed by a description of the methodology; a presentation and analysis of the results; and a conclusion outlining contributions, limitations, as well as potential avenues for further research. While past studies have confirmed the learning benefits of business simulations, the role played by TBL has been overlooked. The key contribution of our work is to highlight that authentic TBL is an important mechanism for enhancing the learning outcomes of online business simulations across multiple cohorts of students studying in different institutional contexts.

\section{Literature Review}

This study is broadly situated within a constructivist education paradigm, with a focus on the use of simulations as an instructional strategy grounded in social constructivism. Social constructivists argue that learners construct knowledge through a social process of meaning-making founded on interaction and collaboration (Vygotsky 1978; Piaget 1952; Brown, Collins and Duguid 1989). Collaborative learning techniques have frequently been examined as a means to develop a range of skills and knowledge through socially constructed meaning (e.g. Johnson, Johnson and Smith 1998; Terenzini et al. 2001; So and Brush 2008). Both high and low achievers in collaborative learning teams have been shown to outperform their counterparts in individual learning environments (Ocker and Yaverbaum 2004). Similarly, student learning outcomes were perceived to be higher in collaborative online courses than in courses where students worked individually (Arbaugh and Benbunan-Finch 2006).

The socio-affective and cognitive dimensions of collaborative learning have been examined in a number of studies (e.g. Terenzini et al. 2001; Proenca 2009; Huang, Rauch and Liaw 2010; Chaparro-Peláez et al. 2013). Cognitive 
theories of collaborative learning examine the influence of collaboration and communication on individual learning (Dillenbourg, Järvelä and Fischer 2009). Social learning theories contend that collaborative learning involves social interaction with a community of learners and teachers and the acquisition and sharing of experiences or knowledge (Zhu 2012). LaPointe and Gunawardena (2004) found that these social interactions had a strong effect on the learning outcomes reported by students.

Collaborative learning methods have been shown to promote both socio-affective and cognitive learning, resulting in higher levels of learner satisfaction (Chaparro-Peláez et al. 2013; Ocker and Yaverbaum 2004). However, as Dillenbourg (1999) observed almost two decades ago, collaborative learning includes such a wide variety of approaches that any effort to agree on a shared understanding of the term would be unproductive. He observes that: "the broadest definition of 'collaborative learning' is that it is a situation in which two or more people learn or attempt to learn something together" (p.1). To move our discussion beyond this broad definition, we focus our attention to team-based learning (TBL) as a more specific collaborative learning approach.

\section{Authentic Team-Based Learning}

There can be very little doubt that the ability to work in a team is one of the most highly sought-after skills in business. A cursory glance at the skills mentioned most frequently in business-related job advertisements clearly reveals an employer penchant for teamwork and collaboration skills. In Australia, teamwork and collaboration skills feature prominently in statements of graduate attributes for most public universities. The national Core Skills for Work Framework explicitly acknowledges the importance of 'connecting and working with others.' According to the framework, this skill area is about "building the work-related relationships needed to achieve an outcome within a workgroup, or achieve goals through team-based collaborations" (DIISRTE 2013, p.29). The Australian Qualifications Framework (AQF) also mandates that learners should be provided with opportunities to develop collaborative skills through participation in teams (Australian Qualifications Framework Council 2013).

Given the aforementioned benefits of collaborative learning and the importance of teamwork skills, it is not surprising to find that many business schools require students to participate in teams to accomplish learning and 
assessment tasks. The co-creation and co-construction of knowledge requires interaction and interdependence between team members (Chaparro-Peláez, et al. 2013; Gros and Lopez 2016; Van den Bossche et al. 2006). Interaction, in this context, refers to the relationships established amongst team members and is seen as central to performance and satisfaction. Following Thibaut and Kelley (1959), interdependence means that group members must perceive some value in working together. This can be established through task or role interdependence, shared team goals and the creation of complementary roles for each team member (Palloff and Pratt 2005). We argue that many common team learning and assessment activities designed by business educators require limited interaction to successfully perform the task. The learning design often does not require task or role interdependence and students therefore perceive little value in working collaboratively to define and achieve common goals, co-create knowledge and share experiences. As a consequence, students respond by dividing the task amongst team members who work independently to complete component parts. This tendency for students to compartmentalize team projects limits opportunities for the development of higher order business skills.

A number of authors have argued that knowledge should be situated in the activities, context, and culture in which it is developed and applied (Brown, Collins and Duguid 1989). Collins, Brown and Holum (1991) proposed a 'cognitive apprenticeship' learning model that focusses on easily observable, real-world tasks where the skills that are developed are inherent in the task itself. More recently, Herrington and Oliver (2000) have built on this work by developing an instructional design framework for authentic learning environments that includes nine key elements. The authentic learning framework recommends that knowledge should be constructed collaboratively using learning contexts and activities that reflect the way knowledge and skills will be used in real-life. This notion of authenticity is similar to discussions about context fidelity and psychological fidelity in other parts of the education literature, notably in simulation-based training (Beaubien and Baker 2004; Reeves and Okey 1996).

We build upon these ideas in this paper by focusing on 'authentic team-based learning', or authentic TBL. Based on the literature discussed above, we propose that authentic TBL consists of authentic contexts and activities that require interaction and interdependence between team members to produce skills development and knowledge cocreation. We argue that online business simulations, when combined with appropriate pedagogies and assessment, provide one example of a learning environment that contains all of these elements. 


\section{Online Business Simulations}

Simulations have become an increasingly popular teaching and learning tool in higher education. Simulations offer a number of advantages over other experiential learning methods, including greater interaction in teamwork and collaborative learning (Drake, Goldsmith and Strachan 2006), and enhanced learner engagement (Fripp 1997; Feinstein, Mann and Corsun 2002; Edelheim and Ueda 2007). A recent Australian audit has estimated that there are over 50 commercially available online business simulations (Benckendorff et al. 2015).

Some business simulations focus on specific functional areas of business such as accounting, finance, marketing or business ethics, while others adopt an enterprise-wide approach that emphasizes the relationships between the various functional areas of an organization. The scope of this study is limited to enterprise-wide online business simulations that encourage learners to step outside their disciplinary focus by engaging in cross-functional decision making and problem-solving (Clarke 2009). These authentic business simulations typically require team members to take responsibility for specific functional areas while interacting with each other to obtain successful outcomes for their organization. More importantly, the cross-functional nature of enterprise-wide simulations increases interdependence between team members.

The use of teams in simulation-based training is well established in medicine and allied health education (Beaubien and Baker 2004; Shapiro et al. 2004). Many simulation-based pedagogies are designed to encourage students to actively engage in collaborative learning modes (Ocker and Yaverbaum 2004; Drake, Goldsmith and Strachan 2006). Despite the fact that many online business simulations require students to collaborate in teams, only a small number of studies have examined the role of teamwork and learning outcomes (Anderson 2005; Chasteen 2016; Drake, Goldsmith and Strachan 2006; Jensen 2003; Martín-Pérez, Martín-Cruz and Pérez-Santana 2013). For example, Coffey and Anderson (2006) found that team dynamics influenced the perceived value students placed on the learning experience. Similarly, Xu and Yang (2010) found that team interaction and psychological safety within a team supported synergistic knowledge development. However, evidence of the true benefits of authentic TBL remain somewhat elusive in the context of business simulations. 


\section{Learning Outcomes and Satisfaction}

The literature generally supports the notion that business simulations are effective at developing critical thinking, problem-solving, and cross-functional decision-making skills (Chakravorty and Franza, 2005; Clarke, 2009). It has been suggested that simulations have a particular pedagogical value when focused on the development of decisionmaking and interpersonal skills within teams (Lamont, 2001; Drake, Goldsmith and Strachan, 2006). This is because the interactive and interdependent environment created by many simulations can foster the development of social skills required by teams to solve problems (Dimitropoulos, Manitsaris and Mavridis, 2008; Huang, Rauch and Liaw, 2010). An exploratory qualitative study by Devitt et al. (2015) provides further support for the notion that teambased simulations enhanced interpersonal skills such as communication, negotiation, decision-making, leadership and conflict management. The outcomes of simulation-based learning can also be evaluated by assessing how students perceive their learning experience (Schumann, Anderson, Scott and Lawton, 2001). Koh et al. (2010) tested the extent to which simulation-based learning met students' perceived satisfaction of psychological needs and motivation.

Studies of the learning outcomes of simulations have, however, produced mixed results (Anderson and Lawton, 2009; van Staalduinen and de Freitas, 2011; Keys and Wolfe, 1990). This is primarily because the measurement of learning outcomes is complex. Some researchers have attempted to use objective measures such as student grades and simulation performance while others have measured student perceptions of acquired learning outcomes.

Objective measures of student performance, such as grades for exams and assessment tasks related to the simulation have been found to be problematic because they do not account for the skills and knowledge students bring to the learning context prior to commencing the simulation. Given these challenges, many authors have relied on selfreported measures of skills and knowledge acquisition. While these measures are more subjective, they allow for individuals to reflect on their learning through a process of internal benchmarking by comparing skills and knowledge prior to the simulation with skills and knowledge acquired during the simulation. While this approach is not without criticism (Bowman, 2010; Porter, 2011), several recent studies have continued to affirm the validity of self-reported learning outcomes, particularly when students are required to reflect over shorter time periods (Anaya, 1999; Pike, 2011; Douglass, Thomson and Zhao, 2012). furthermore, some of the limitations of quantitative self- 
reported measures can be overcome by adopting a mixed methods design that includes qualitative findings (Creswell, 2002).

While many authors have examined learning outcomes and student satisfaction, these concepts are usually treated separately as dependent variables. Few studies have examined the notion that the accomplishment of learning outcomes may mediate the relationship between teaching and learning approaches such as TBL and student satisfaction.

\section{Methodology}

The methodological design consisted of a mixed methods approach using a sequential explanatory design (Creswell, 2002). The first phase of the data collection consisted of a self-administered questionnaire designed to measure student perceptions of teamwork, learning outcomes and satisfaction. Following this quantitative phase, focus groups were conducted to further explore students' understanding of teamwork and its impact on student learning.

\section{Quantitative Sample and Data Collection}

The quantitative data collection consisted of two stages: (1) a pilot study to refine the questionnaire, and (2) primary data collection. Data for the pilot study were collected in early 2014 from 166 students studying at a tertiary institution in Australia. Following this, primary data were collected in 2014 and 2015 from seven tertiary education institutions in Australia and one in Hong Kong. The sampling strategy was designed to increase the diversity of students and simulations to allow for the results to be more generalized. The sample included courses covering topics such as strategy, service operations, corporate social responsibility, human resource management, aviation management and managerial decision making. Self-administered questionnaires were distributed to undergraduate and postgraduate students either in hard copy provided in class or through an online link. The survey was administered at the end of the teaching period once students had already finished their interaction with the simulation. A total of 400 surveys were completed, with the final sample consisting of 365 valid surveys. A profile of the sample is presented in Table 1. 
Table 1: Profile of Respondents

\begin{tabular}{|c|c|c|}
\hline Characteristics & No. & Percentage \\
\hline \multicolumn{3}{|l|}{ Gender $(n=356)$} \\
\hline Female & 238 & $66.9 \%$ \\
\hline Male & 118 & $33.1 \%$ \\
\hline \multicolumn{3}{|l|}{ Age groups $(n=346 ;$ mean $=23.9)$} \\
\hline 19 to 21 years & 76 & $22.0 \%$ \\
\hline 22 to 24 years & 177 & $51.2 \%$ \\
\hline 25 to 30 years & 77 & $22.3 \%$ \\
\hline Over 30 years & 16 & $4.6 \%$ \\
\hline \multicolumn{3}{|l|}{ Nationality $(n=365)$} \\
\hline Hong Kong & 88 & $24.1 \%$ \\
\hline China & 81 & $22.2 \%$ \\
\hline Australia & 72 & $19.7 \%$ \\
\hline South Korea & 27 & $7.4 \%$ \\
\hline Japan & 10 & $2.7 \%$ \\
\hline Malaysia & 10 & $2.7 \%$ \\
\hline Vietnam & 10 & $2.7 \%$ \\
\hline Other & 67 & $18.4 \%$ \\
\hline \multicolumn{3}{|l|}{ Student Characteristics* $(n=365)$} \\
\hline Studying part-time & 26 & $7.1 \%$ \\
\hline Studying externally & 27 & $7.4 \%$ \\
\hline Non-English-speaking background & 199 & $54.5 \%$ \\
\hline Working part-time & 154 & $42.2 \%$ \\
\hline Working full-time & 32 & $8.8 \%$ \\
\hline \multicolumn{3}{|l|}{ Year Level $(n=350)$} \\
\hline First year & 50 & $14.3 \%$ \\
\hline Second year & 26 & $7.4 \%$ \\
\hline Final year & 223 & $63.7 \%$ \\
\hline Postgraduate & 51 & $14.6 \%$ \\
\hline \multicolumn{3}{|l|}{ Simulation Used $(n=365)$} \\
\hline HOTS & 237 & $64.9 \%$ \\
\hline IDLE & 60 & $16.4 \%$ \\
\hline Airline Online & 28 & $7.7 \%$ \\
\hline Ramsden & 25 & $6.8 \%$ \\
\hline RevSim & 15 & $4.1 \%$ \\
\hline \multicolumn{3}{|l|}{ Institution ( $n=363)$} \\
\hline Griffith University & 231 & $63.6 \%$ \\
\hline The University of Wollongong & 60 & $16.5 \%$ \\
\hline The University of South Australia & 25 & $6.9 \%$ \\
\hline The University of Queensland & 20 & $5.5 \%$ \\
\hline William Angliss Institute & 15 & $4.1 \%$ \\
\hline International College of Management Sydney & 11 & $3.0 \%$ \\
\hline La Trobe University & 1 & $0.3 \%$ \\
\hline
\end{tabular}

The majority of respondents were full time students (92.9\%) in the final year of their undergraduate studies (63.7\%).

Sixty-seven percent were female students and $51.2 \%$ were between 22 to 24 years of age. Despite most of the data collection taking place in Australia, the majority of students were from Hong Kong (24.1\%) and China (22.2\%), 
followed by Australia (19.7\%). More than half of the students (54.5\%) came from a non-English speaking background (NESB) and almost half of the students (42.2\%) were in part-time/casual employment whilst studying.

All simulations included in the sample were total enterprise business simulations requiring students to work in teams to set up a business and to achieve various business goals. All of the simulations were run over a number of weeks to allow students to experience several business cycles. In all cases teams competed against each other in a virtual marketplace. Teams were required to make decisions about operations, strategy, marketing, human resources, finance and sustainability within each cycle. Students had to work together in teams because the success of their business was predicated in a high level of task interdependence. Decisions and actions undertaken in one area of the simulated business impacted on other aspects of the business. The courses within which the simulations were undertaken were typically advanced final year or postgraduate courses where the learning outcomes required learners to work in a team to integrate and apply business knowledge and skills. In order to achieve these outcomes, students completed a number of teamwork learning and assessment activities, including developing a business plan or proposal, setting up the online business, analyzing and reporting on business performance and making decisions about the business and its operations.

\section{Measures}

The questionnaire consisted of statements measuring the key constructs of interest within the model including perceptions about teamwork (independent variable), perceptions about acquired learning outcomes (mediator/dependent variable) and student satisfaction (dependent variable). Respondents were asked to indicate their level of agreement with each statement using a seven-point Likert scale ( $1=$ Strongly Disagree $\ldots .7=$ Strongly Agree). The questionnaire included seventeen statements about teamwork adapted from Chaparro-Peláez et al. (2013), Coffey and Anderson (2006), Huang, Rauch, and Liaw (2010), Hurme (2010), and Ocker and Yaverbaum (2001). Perceived learning outcomes included a mix of fourteen statements about business knowledge and skills adapted from Kendall and Harrington (2003), Martin and McEvoy (2003), and Vos and Brennan (2010). Learner satisfaction was measured by evaluating satisfaction with the simulation itself, the use of the simulation as a learning tool and whether the simulation met expectations. Eleven items were adapted from Chaparro-Peláez et al. (2013), 
Martin and McEvoy (2003), Lo (2010), and Teo and Wong (2013). Respondents in the pilot study indicated the survey was easy to follow but identified several issues with wording and some statements were adjusted to ensure face validity. The full set of statements used in the final questionnaire are included in Appendix 1 at the end of this paper.

Qualitative Sample and Data Collection

In order to complement the data collected through the survey, focus groups were conducted with students who used one of the simulations. The purpose of the focus groups was twofold. Firstly, we were interested in hearing the team members discussing team dynamics and their satisfaction with the simulation as part of their learning experience. Secondly, it was also an opportunity for the research team to gain further insight into the responses obtained in the survey. Three focus groups, comprising a total of 14 students, were conducted across two institutions in Australia. One of the focus groups consisted of five postgraduate students using Airline Online, while the other two groups consisted of two teams with four and five undergraduate students using HOTS. Groups were chosen based on their performance, two very successful groups and one that struggled to succeed in terms of profitability of their online business. The focus group sessions lasted for approximately 30 minutes each. Saturation of opinions was detected following the transcription of the three focus groups and it was determined that additional focus groups would not provide further insights.

\section{Results}

Quantitative Results

Before analyzing the data, the dataset was cleaned by removing invalid responses. The analysis included two stages. The first stage was designed to evaluate the measurement model through the use of exploratory factor analysis (EFA) and confirmatory factor analysis (CFA). The second stage included the development, testing and analysis of the structural model. The proposed model was tested to determine simultaneous relationships between the latent variables and the overall fit of the model to the data. Exploratory factor analysis was conducted using the Statistical Package for the Social Sciences (SPSS 25.0), while confirmatory factor analysis was computed using AMOS 25.0. Structural equation modeling (SEM) was used to analyze the proposed relationships. 
Exploratory factor analysis was conducted on the pilot study data and was conducted on all items within the proposed model. This step was taken since some elements of the measurement model were previously untested. The final solution resulted in three factors: labeled teamwork, learning, and satisfaction. The total variance explained by the three factors was $71 \%$. The maximum likelihood extraction method was used due to the skewness of the data, with Kaiser-Meyer-Olkin measure of sampling adequacy $=0.96$. Bartlett's test of sphericity results were $\chi^{2}=9922.8$ $d f=351, p<0.000$.

Teamwork in the context of online business simulations consisted of twelve items, as presented in the Appendix 1. These items were a combination of socially shared metacognition, interaction and interdependence. The perceived learning outcomes factor comprised seven items and the student satisfaction factor contained eight items (see Appendix 1). To confirm the measurement model, a subsequent confirmatory analysis was conducted on the primary dataset to evaluate and refine the resulting scales (Gerbing and Anderson, 1988). Confirmatory factor analysis was conducted to confirm the structure found in the exploratory factor analysis (EFA). The CFA model with all the scale items from the EFA resulted in a good fit to the data $\left(\chi^{2}=906.5(d f=321, p<.00), \chi^{2} / d f=2.8\right.$, CFI $=0.94$, RMSEA $=0.07(0.06,0.07)$ and SRMR $=0.04$. $)$ The chi-square was significant, but this result was expected due to sample size (Anderson and Gerbing, 1988; Hair, Black, Babin, and Anderson, 2014). The normed chi-square was just above the recommended cut-off of 2.0 but less than 3.0. The CFI was under .95 and the RMSEA value was just slightly above the recommended good fit of 0.05 . The SRMR was well below the marginal acceptance level of 0.08 (Hair, Black, Babin, and Anderson, 2014).

Although the fit indicators suggest an adequate fit, a few standardized residuals were greater than 4.0, which is an indication of problems or misfit (Hair, Black, Babin and Anderson, 2014). One item used to measure teamwork was of concern and was deleted from the model, as it did not represent a unique attribute. Further evaluation identified a similar problem with learning outcomes, with two items deleted from the model. The removed statements referred to understanding specific business functions such as planning and marketing. These items may be less reliable across multiple cohorts because student responses are likely to vary based on the features of particular simulations as well as comfort, familiarity and competence across three significantly different disciplines. The final constructs and items 
are shown in Table 2. This revised CFA model resulted in a better fitting model $\left(\chi^{2}=437.4(d f=225, p<.000), \chi^{2} / d f\right.$

$=1.9, \mathrm{CFI}=0.97, \mathrm{RMSEA}=0.05(0.04,0.06)$ and $\mathrm{SRMR}=0.03)$. The chi-square was significant; however, the normed chi-square was below the recommended cut-off of 2.0. Both the CFI and RMSEA values were below the recommended good fit of 0.05. SRMR was well below the marginal acceptance level of 0.08 . As teamwork was originally expected to be a multivariate construct, two indicator errors were found to be correlated and were freed due to the theoretical nature of the constructs: 'my team was dedicated to the task' an 'my team worked well together'. In order to cross validate the model, a random set of responses were drawn from the sample and subsequent analysis resulted in a good fitting model $\left(\chi^{2}=454.9(d f=225, p<.000), \chi^{2} / d f=2.0, \mathrm{CFI}=0.95, \mathrm{RMSEA}\right.$ $=0.07(0.06,0.07)$ and $\mathrm{SRMR}=0.04)$

Table 2: Factors and reliability measures

\begin{tabular}{|c|c|c|c|}
\hline Constructs & $\begin{array}{c}\begin{array}{c}\text { Standardis } \\
\text { ed }\end{array} \\
\text { regression } \\
\text { weights }\end{array}$ & $\begin{array}{l}\text { Construct } \\
\text { reliability }\end{array}$ & $\begin{array}{c}\text { Average } \\
\text { variance } \\
\text { extracted }^{\mathrm{b}}\end{array}$ \\
\hline \multicolumn{4}{|l|}{ Teamwork } \\
\hline My team interactions helped me to understand other points of view & 0.910 & 0.967 & 0.726 \\
\hline My team worked well together & 0.896 & & \\
\hline $\begin{array}{l}\text { I was able to learn new skills and knowledge from other members in } \\
\text { my team }\end{array}$ & 0.877 & & \\
\hline $\begin{array}{l}\text { The unique skills and talents of each team member was fully valued } \\
\text { and utilized }\end{array}$ & 0.872 & & \\
\hline My team actively exchanged ideas using online tools & 0.849 & & \\
\hline $\begin{array}{l}\text { Most of the time, members of my team asked each other for feedback } \\
\text { on their work }\end{array}$ & 0.845 & & \\
\hline My team was dedicated to the task & 0.838 & & \\
\hline Key decisions about our company were made by the entire team & 0.832 & & \\
\hline Team members acknowledged the points of view of others & 0.823 & & \\
\hline Working as a team allowed me to work smarter, not harder & 0.814 & & \\
\hline $\begin{array}{l}\text { The contributions of other team members assisted my understanding } \\
\text { of the simulation }\end{array}$ & 0.813 & & \\
\hline \multicolumn{4}{|l|}{ Learning Outcomes } \\
\hline Understanding of operations & 0.877 & 0.898 & 0.638 \\
\hline Understanding of strategic management & 0.820 & & \\
\hline Problem-solving skills & 0.788 & & \\
\hline Understanding of staffing & 0.766 & & \\
\hline Understanding of finance & 0.736 & & \\
\hline \multicolumn{4}{|l|}{ Satisfaction } \\
\hline Overall, I am satisfied with the simulation as a learning tool & 0.904 & 0.956 & 0.755 \\
\hline Overall, I learned a lot from the simulation & 0.897 & & \\
\hline Overall, the simulation has met my expectations & 0.887 & & \\
\hline $\begin{array}{l}\text { I am satisfied with the online software application used for the } \\
\text { simulation }\end{array}$ & 0.867 & & \\
\hline
\end{tabular}


The skills and knowledge learnt during the simulation will be useful for my future career

I enjoyed learning with the simulation

The simulation made the course more interesting

0.840

${ }^{a}$ Construct validity was computed for each factor using Cronbach's alpha (Hair, Black, Babin and Anderson, 2014).

${ }^{\mathrm{b}}$ The average variance extracted was computed as an indicator of convergent validity (Hair, Black, Babin and Anderson, 2014).

The construct reliability of all factors was assessed using Cronbach's alpha. Reliability for all factors was above 0.89, indicating that these measures consistently represent the same latent construct (Hair, Black, Babin and Anderson, 2014). For convergent validity, the average variance extracted (AVE) for each latent construct was calculated and found to be greater than 0.5 , as shown in Table 2 . This confirms convergent validity for the model. As the AVE is sensitive to a lack of convergent validity, it can be used to assess discriminant validity. For discriminant validity to be confirmed, the AVE must exceed the squared correlation between the two factors, as shown in Table 3.

Table 3: Means, Standard Deviations, and Construct Correlations

\begin{tabular}{lccccc}
\hline \multicolumn{1}{c}{ Variables } & M & SD & TW & LO & SAT \\
\hline Teamwork (TW) & 5.649 & 1.103 & 1.000 & & \\
Learning outcomes (LO) & 5.412 & 0.981 & 0.404 & 1.000 & \\
Satisfaction (SAT) & 5.371 & 1.198 & 0.504 & 0.798 & 1.000 \\
\hline
\end{tabular}

The final step in the analysis process involved investigation of the relationships among the latent variables through the structural model using maximum likelihood estimation. The structural model contains one exogenous latent variable of teamwork, and two endogenous latent variables of student learning outcomes and student satisfaction. See Appendix 1 for final constructs and items.

The overall fit of the structural model to the data was $\operatorname{good}\left(\chi^{2}=437.4(d f=225, p<.000), \chi^{2} / d f=1.94, \mathrm{CFI}=0.97\right.$, RMSEA $=0.05(.04, .05)$, and SRMR $=0.03)$. There was a significant relationship between teamwork and perceived learning outcomes $(\mathrm{b}=0.403, \mathrm{p}<.05)$. There was also a strong relationship between perceived learning outcomes and student satisfaction $(\mathrm{b}=0.708, \mathrm{p}<.05)$ thus supporting the direct effect of the mediator on the outcome variable.

Teamwork had a significant direct influence on student satisfaction $(\mathrm{b}=0.218, \mathrm{p}<.05)$. However, perceived learning 
outcomes mediated student satisfaction, as shown in Table 4. An alternative model was tested to determine if there was only an indirect effect from teamwork to student satisfaction. The results were significantly worse $\left(\chi^{2}=467.57\right.$ $(d f=226, p<.000), \chi^{2} / d f=2.07, \mathrm{CFI}=0.97, \mathrm{RMSEA}=0.05(.04, .06)$, and SRMR $\left.=0.07\right)$, so the direct path was retained in the model. The full results of the model are shown in Figure 1.

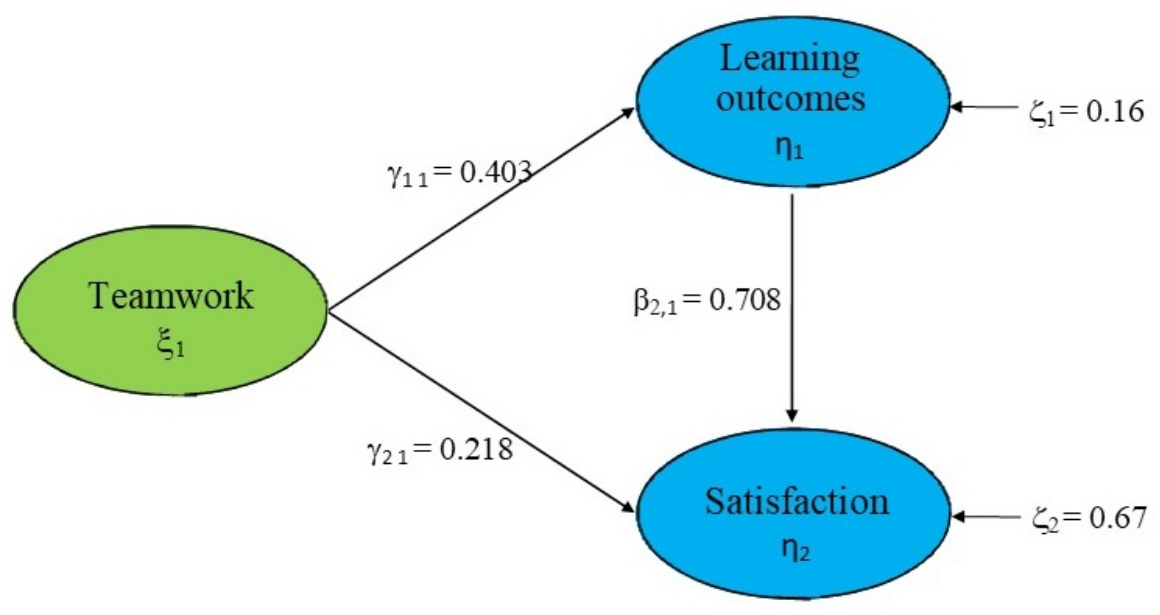

Figure 1: Teamwork, learning outcomes and satisfaction results.

Table 4: Structural model: Direct and Indirect Effects of Teamwork on Learning Outcomes and Satisfaction

\begin{tabular}{lcccc}
\hline Constructs & Direct effects & $\begin{array}{c}\text { Indirect } \\
\text { effects }\end{array}$ & Total effects & Hypothesis \\
\hline Teamwork $\rightarrow$ Learning outcomes & $0.403^{*}$ & & $0.403^{*}$ & Supported \\
Teamwork $\rightarrow$ Satisfaction & $0.218^{*}$ & $0.286^{*}$ & $0.504^{*}$ & Supported \\
Learning outcomes $\rightarrow$ Satisfaction & $0.708^{*}$ & & $0.708^{*}$ & Supported \\
\hline
\end{tabular}

$\mathrm{N}=365$. Standardized effects provided. ${ }^{*} \mathrm{p}<0.05$

\section{Qualitative Results}

The qualitative results from the student focus groups add further insight to the structural model. The focus groups were recorded and comments were transcribed and subjected to a thematic analysis. Key themes and concepts were coded manually by reading the transcripts and creating a list of recurring concepts (Braun and Clarke, 2006). These concepts were then combined into themes. This process was undertaken independently by three researchers who then compared and combined their coding schemes and findings. This process was used to reduce the inherent 
subjectivity associated with coding qualitative data. Key themes included (1) the importance of communication, (2) interdependence of team roles, (3) limited opportunities to learn from other teams, (4) the skills developed through team interactions that were perceived to be authentic, and (5) the impact of teamwork on student satisfaction. These themes and the respective notes and direct quotes provided during the focus groups are presented at Table 5 .

Table 5: Key themes and indicative quotes from the focus groups

\begin{tabular}{|c|c|}
\hline Key themes & Notes from focus groups or students' quotes \\
\hline $\begin{array}{l}\text { Importance of } \\
\text { communication }\end{array}$ & $\begin{array}{l}\text { Communication between the team-members was mentioned as a very important skill for the } \\
\text { overall performance of the team: } \\
\text { I don't think I've ever communicated so much with my team members in a group before. } \\
\text { Ten o'clock at night I'd be messaging [another student]. It was just constant. } \\
\text { The ability to listen to other points of view and resolve conflict was a key learning outcome: } \\
\text { The marketing manager would always argue with the finance manager. Since the } \\
\text { finance manager would always say 'keep your eyes on your budget or your forecasting } \\
\text { allowance for a year you're spending'. But the marketing manager would say 'how am I } \\
\text { supposed to increase my productivity or advertising efficiency if I can't spend any } \\
\text { money'? So ... they actually have to compromise and find other alternatives. }\end{array}$ \\
\hline $\begin{array}{l}\text { Interdependence } \\
\text { of team roles }\end{array}$ & $\begin{array}{l}\text { The interdependence of organisational roles and competitive nature of the simulation } \\
\text { required then to work more closely with their team-members: } \\
\text { This is one of those team assignments where if you did have one member that wasn't as } \\
\text { involved as the rest it would really let down the whole team. [...] This is one of those } \\
\text { assignments where everybody really does have to contribute equally. }\end{array}$ \\
\hline $\begin{array}{l}\text { Limited } \\
\text { opportunities to } \\
\text { learn from other } \\
\text { teams }\end{array}$ & $\begin{array}{l}\text { It was difficult to learn from peers outside their team as they perceived that any help would } \\
\text { hinder their final performance in the simulation: } \\
\text { We didn't have any communication with other teams because our class was extremely } \\
\text { competitive. It seemed like nobody wanted to share their secrets with anybody else [...] } \\
\text { So, we would have loved to have been able to talk to other groups to see what they were } \\
\text { doing. }\end{array}$ \\
\hline $\begin{array}{l}\text { Skills developed } \\
\text { through authentic } \\
\text { team interactions }\end{array}$ & $\begin{array}{l}\text { The simulation provided authentic opportunities to solve problems collaboratively, manage } \\
\text { conflict and make decisions: } \\
\text { I learned that every single decision being made by every team member could potentially } \\
\text { affect my role... You can't really separate everything... accountability is really spread } \\
\text { across the team. } \\
\text { The results of the weekly batches allowed students to develop problem-solving skills that } \\
\text { really help us to make decisions or come up with solutions in a short time. }\end{array}$ \\
\hline $\begin{array}{l}\text { Impact on student } \\
\text { satisfaction }\end{array}$ & $\begin{array}{l}\text { Unlike other forms of group work, the simulation provided a sense of meaningful teamwork. } \\
\text { I'm the first person to say I absolutely hate teamwork...I hate teamwork with a passion. } \\
\text { It's probably because I've never had a good team but this time I've had a good team. } \\
\text { Yeah, overall, I do think the simulation was beneficial to my learning and it helps } \\
\text { working in a team, it was great. }\end{array}$ \\
\hline
\end{tabular}


Overwhelmingly, students found that the teamwork enhanced their learning and problem-solving. In addition, the simulation provided an authentic learning experience. One negative aspect identified by all participants was the amount of time they spent on the simulation, constantly checking their performance and improving their decisions as required since business cycles occurred on a weekly or bi-weekly schedule. Hence, time management skills were identified as paramount to successfully juggling the extra load required by the simulation with other teaching, work or personal commitments.

Overall, students appreciated the opportunity offered to learn from the simulation, with some statements to support this claim including "apply the knowledge in a more practical way", having the opportunity to make mistakes that "probably people won't forgive" in the real world, viewing the simulation as "something special that you will always remember", and acknowledging that "hands-on experience is important."

\section{Discussion and Conclusion}

Our findings indicate that authentic TBL can encourage students to cooperate, exchange ideas and share experiences to develop knowledge and skills. We have also identified that online business simulations provide an authentic learning context for students to develop and apply management knowledge and problem-solving skills. Both the quantitative and qualitative analyses indicate that online business simulations create opportunities for authentic TBL that enhance self-reported learning outcomes. Furthermore, our quantitative modeling has demonstrated that these synergies enhance student enjoyment and satisfaction with the learning experience.

The data collected from the survey and focus groups identify the important role of authentic TBL in enhancing the learning outcomes and satisfaction reported by students after using a business simulation. The dynamic and crossfunctional nature of the simulations included in this study created interdependencies and encouraged frequent and meaningful interactions between team members. The need to engage with other team members and to understand their points of view was critical to maintaining a competitive business and developing vital teamwork skills. Rather than synthesizing parts of an assignment as most team-based activities require, individuals adopted specific 
functional roles resulting in divergent opinions about how to advance the virtual organization. This context allowed for disagreements to flourish and forced individuals to consider and learn from the perspectives of other team members, thereby creating an interdependent learning community grounded in practice.

The authentic nature of the simulation, mirroring a number of managerial and operational decisions made in real world organizations, also provided opportunities to acquire or improve problem-solving skills and understand operations and strategic management. Students indicated that the simulation provided the opportunity to understand 'real world' problems faced by organizations. Students also stated their satisfaction with the use of simulations as a learning tool and the enjoyment of learning with the use of simulation.

These findings make several conceptual and practical contributions. Conceptually, this paper provides evidence that TBL plays an important role in enhancing the learning outcomes reported by students after using an online business simulation. This finding conforms with the social constructivist perspective of learning, which argues that knowledge and skills acquisition is enhanced by interactions with peers. The practical implication of this finding is that educators need to consider how opportunities for socially constructed meaning can be supported and embedded into the curriculum. Non-traditional pedagogies that incorporate authentic TBL can support collaboration and provide learners with opportunities to experience multiple perspectives. Innovations such as flipped classrooms provide opportunities for teams to interact during class time, allowing the instructor to become a facilitator of learning. Team interaction can also be encouraged outside the classroom by guiding students to use readily available online collaborative tools such as wikis, Facebook pages and Skype. The qualitative analysis highlights that learning activities should not only support and encourage interaction within teams, but also foster an understanding of the dynamics of competition between teams.

This study presented both quantitative and qualitative results based on self-reported measures of learning outcomes. A cross-sectional mixed-methods design was adopted to add further insight as recommended by Creswell (2002). However, this approach also a number of limitations that highlight opportunities for future research. First, while the qualitative results confirmed the quantitative analysis, future studies may benefit from including objective measures of learning gains alongside self-reported measures. Second, the study was based on a large sample of students 
consisting of several cohorts using different business simulations. Our key argument is that authentic TBL is an important mechanism for enhancing the learning outcomes of online business simulations across multiple cohorts of students studying in different institutional contexts. The cross-sectional methodological approach was therefore not designed to analyze or control for differences between cohorts, but rather to identify consistent patterns and relationships that can be generalized across all cohorts. The model that emerged from our analysis was robust and stable and further reinforced by the qualitative data. Nevertheless, we acknowledge that differences in student characteristics, teaching approaches and pedagogical may influence learning outcomes. It would therefore be useful to conduct further research on the influence of teamwork on simulation learning outcomes in other cultural settings and learning contexts, as identified by Stepanyan, Mather, and Dalrymple (2014). The understanding, expectations, interactions and outcomes of TBL are likely to be influenced by the cultural and anthropological backgrounds of learners. A comparison of differences between collectivist and individualistic cultures, or Confucian and Western learners would be instructive. In addition, it would be interesting to measure how simulations could enhance learning outcomes by tracking and analyzing the progress of one cohort of students using simulations across several years of study. Likewise, it would be useful to compare the use of authentic TBL in simulations with situations where students were required to use simulations on their own.

This study focused on the student perspective. Including graduates and alumni in future studies would provide additional insight into whether participation in online business simulations resulted in improved employment or promotion outcomes. It would also be beneficial to explore instructors' views about the value of teamwork in facilitating the acquisition and development of learning outcomes when using online business simulations. This line of inquiry might focus on the pedagogies, assessment and support mechanisms instructors use to encourage meaningful team interactions that optimize learning outcomes.

\section{References}

Anaya, G. (1999). College impact on student learning: Comparing the use of self-reported gains, standardized test scores, and college grades. Research in Higher Education, 40(5), 499-526.

Anderson, J. R. (2005). The Relationship Between Student Perceptions of Team Dynamics and Simulation Game Outcomes: An Individual-Level Analysis. Journal of Education for Business, 81(2), 85-90. 
Anderson, P. H., \& Lawton, L. (2009). Business simulations and cognitive learning: Developments, desires, and future directions. Simulation \& Gaming, 40(2), 193-216.

Arbaugh, J. B., \& Benbunan-Finch, R. (2006). An investigation of epistemological and social dimensions of teaching in online learning environments. Academy of Management Learning \& Education, 5(4), 435-447.

Arias, J. J., \& Walker, D. M. (2004). Additional evidence on the relationship between class size and student performance. The Journal of Economic Education, 35(4), 311-329.

Australian Qualifications Framework Council. (2013). Australian Qualifications Framework (Second Edition). Adelaide: Australian Qualifications Framework Council.

Beaubien, J. M., \& Baker, D. P. (2004). The use of simulation for training teamwork skills in health care: how low can you go? Quality and Safety in Health Care, 13(suppl 1), i51-i56.

Benckendorff, P., Lohmann, G., Pratt, M., Reynolds, P., Strickland, P., \& Whitelaw, P. (2015). Enhancing Student Learning Outcomes with Simulation-based Pedagogies: Final Report 2015. Sydney: Australian Government Office for Learning and Teaching.

Bowman, N. A. (2010). Can 1st-year college students accurately report their learning and development? American Educational Research Journal, 47(2), 466-496.

Braun, V., \& Clarke, V. (2006). Using thematic analysis in psychology. Qualitative Research in Psychology, 3(2), 77-101.

Bridgstock, R. (2009). The graduate attributes we've overlooked: Enhancing graduate employability through career management skills. Higher Education Research \& Development, 28(1), 31-44.

Brown J.S., Collins A., \& Duguid P. (1989). Situated cognition and the culture of learning. Educational Researcher, $18(1), 32-42$.

Chakravorty, S. S., \& Franza, R. M. (2005). Enhancing cross-functional decision making: A simulation approach. Decision Sciences Journal of Innovative Education, 3(2), 331-337.

Chaparro-Peláez, J., Iglesias-Pradas, S., Pascual-Miguel, F.J., \& Hernández-García, Á. (2013). Factors affecting perceived learning of engineering students in problem based learning supported by business simulation. Interactive Learning Environments, 21(3), 244-262.

Chasteen, L. (2016). Simulations for strategy courses: Measuring teamwork. Developments in Business Simulation and Experiential Learning, 43(1), 141-146. 
Clarke, E. (2009). Learning outcomes from business simulation exercises: Challenges for the implementation of learning technologies. Education \& Training, 51(5/6), 448-459.

Creswell, J. W. (2002). Research Design: Qualitative, quantitative, and mixed methods approaches (2nd ed.). Thousand Oaks, CA: Sage.

Collins, A., Brown, J. S., \& Holum, A. (1991). Cognitive apprenticeship: Making thinking visible. American Educator, 15(3), 6-11.

Coffey, B. S. \& Anderson, S. E. (2006). The students' view of a business simulation: Perceived value of the learning experience. Journal of Strategic Management Education, 3, 151-168.

Devitt, A., Brady, M., Lamest, M., Dalton, G., Newman, N., \& Gomez, S. (2015). Serious games in marketing education: Developing higher order cognitive skills through collaboration in a simulation game. INTED2015 Proceedings, 6340-6349.

DIISRTE. (2013). Core skills for Work Developmental Framework. Canberra: Commonwealth of Australia. Dillenbourg, P. (1999). Introduction: What do you mean by “collaborative learning”? In Dillenbourg, P. (Ed.), Collaborative Learning: Cognitive and Computational Approaches, pp. 1-19. Oxford: Elsevier.

Dillenbourg, P., Järvelä, S., \& Fischer, F. (2009). The evolution of research on computer-supported collaborative learning. In N. Balacheff, S. Ludvigsen, T. Jong, A. Lazonder, \& S. Barnes (Eds.), Technology-Enhanced Learning, 3-19. New York: Springer.

Dimitropoulos, K., Manitsaris, A., \& Mavridis, I. (2008). Building virtual reality environments for distance education on the web: a case study in medical education. International Journal of Social Sciences, 2(1), $62-70$.

Drake R., Goldsmith G., \& Strachan R. (2006). A novel approach to teaching teamwork. Teaching in Higher Education, 11(1), 33-46.

Douglass, J. A., Thomson, G., \& Zhao, C. M. (2012). The learning outcomes race: The value of self-reported gains in large research universities. Higher Education, 64(3), 317-335.

Edelheim J., \& Ueda D. (2007). Effective use of simulations in hospitality management education - A case study. Journal of Hospitality, Leisure, Sport and Tourism Education, 6(1), 18-28.

Feinstein, A.H., Mann, S., \& Corsun, D.L. (2002). Charting the experiential territory: Clarifying definitions and uses of computer simulation, games, and role play. Journal of Management Development, 21(10), 732-744. 
Fripp, J. (1997). A future for business simulations? Journal of European Industrial Training, 21(4), 138-142.

Gerbing, D. W., \& Anderson, J. C. (1988). An updated paradigm for scale development incorporating unidimensionality and its assessment. Journal of Marketing Research, 25, 186-192.

Giroux, H. A. (2010). Bare pedagogy and the scourge of neoliberalism: Rethinking higher education as a democratic public sphere. The Educational Forum, 74(3), 184-196.

Gros, B., \& López, M. (2016). Students as co-creators of technology-rich learning activities in higher education. International Journal of Educational Technology in Higher Education, 13(1), 28.

Hair, J. F., Black, W. C., Babin, B. J., \& Anderson, R. E. (2014). Multivariate Data Analysis (7th ed.). London: Pearson.

Hansen, R. S. (2006). Benefits and problems with student teams: Suggestions for improving team projects. Journal of Education for Business, 82(1), 11-19.

Herrington, J., \& Oliver, R. (2000). An instructional design framework for authentic learning environments. Educational Technology Research and Development, 48(3), 23-48.

Huang, H.-M., Rauch, U., \& Liaw, S.-S. (2010). Investigating learners' attitudes toward virtual reality learning environments: Based on a constructivist approach. Computers \& Education, 55(3), 1171-1182.

Hurme, T.-R. (2010). Metacognition in group problem solving - A quest for socially share metacognition. University of Oulu, Finland.

Jensen, K. O. (2003). Business games as strategic team-learning environments in telecommunications. $B T$ Technology Journal, 21(2), 133-144.

Johnson, D. W., Johnson R. T., \& Smith K. A. (1998). Cooperative learning returns to college what evidence is there that it works? Change: The Magazine of Higher Learning, 30(4), 26-35.

Kendall, K. W., \& Harrington, R. J. (2003). Strategic management education incorporating written or simulation cases: An empirical test. Journal of Hospitality \& Tourism Research, 27(2), 143-165

Keys, B., \& Wolfe, J. (1990). The role of management games and simulations in education and research. Journal of Management, 16(2), 307-336.

Koh, C., Tan, H. S., Tan, K. C., Fang, L., Fong, F. M., Kan, D., Lye, S. L. \& Wee, M. L. (2010). Investigating the effect of 3D simulation based learning on the motivation and performance of engineering students. Journal of Engineering Education, 99(3), 237-251. 
Lamont, L. M. (2001). Enhancing student and team learning with interactive marketing simulations. Marketing Education Review, 11(1), 45-55.

LaPointe, D. K., \& Gunawardena, C. N. (2004). Developing, testing and refining of a model to understand the relationship between peer interaction and learning outcomes in computer-mediated conferencing. Distance Education, 25(1), 83-106.

Leavitt, H. J. (1989). Educating our MBAs: On teaching what we haven't taught. California Management Review, $31(3), 38-50$.

Lo, C. C. (2010). Student learning and student satisfaction in an interactive classroom. The Journal of General Education, 59(4), 238-263.

Martin, D., \& McEvoy, B. (2003). Business simulations: A balanced approach to tourism education. International Journal of Contemporary Hospitality Management, 15(6), 336-339.

Martín-Pérez, V., Martín-Cruz, N., \& Pérez-Santana, M. P. (2013). Learning teamwork knowledge, skills and abilities: Business simulation vs. case studies. International Journal of Management in Education, 7(4), 376-392.

Mintzberg, H. (1996). Ten ideas designed to rile everyone who cares about management. Harvard Business Review, $74(4), 61-67$.

Ocker, R. J., \& Yaverbaum, G. J. (2004). Collaborative learning environments: Exploring student attitudes and satisfaction in face-to-face and asynchronous computer conferencing settings. Journal of Interactive Learning Research, 15(4), 427-448.

Palloff, R.M., \& Pratt, K. (2005). Collaborating Online: Learning together in community. San Francisco: JoseyBass.

Piaget, J. (1952). The origins of intelligence in children. New York: International Universities Press.

Pike, G. R. (2011). Using college students' self-reported learning outcomes in scholarly research. New Directions for Institutional Research, (150), 41-58.

Pfeffer, J., \& Fong, C. T. (2002). The end of business schools? Less success than meets the eye. Academy of Management Learning \& Education, 1(1), 78-95.

Porter, S. R. (2011). Do college student surveys have any validity? The Review of Higher Education, 35(1), $45-76$. 
Proenca, T. (2009). Self-managed work teams: a lean or an autonomous teamwork model? International Journal of Human Resources Development and Management, 9(1), 59-80.

Reeves, T.C., \& Okey, J.R. (1996). Alternative assessment for constructivist learning environments. In B.G. Wilson (Ed.), Constructivist learning environments: Case studies in instructional design (pp. 191-202). Englewood Cliffs, NJ: Educational Technology Publications.

Schumann, P. L., Anderson, P. H., Scott, T. W., \& Lawton, L. (2001). A framework for evaluating simulations as educational tools. Developments in Business Simulation and Experiential Learning, 28, 215-220.

Shapiro, M. J., Morey, J. C., Small, S. D., Langford, V., Kaylor, C. J., Jagminas, L., Suner, S., Salisbury, M. L., Simon, R. \& Jay, G. D. (2004). Simulation based teamwork training for emergency department staff: does it improve clinical team performance when added to an existing didactic teamwork curriculum? Quality and Safety in Health Care, 13(6), 417-421.

So, H.-J., \& Brush, T.A. (2008). Student perceptions of collaborative learning, social presence and satisfaction in a blended learning environment: Relationships and critical factors. Computers \& Education, 51(1), 318-336.

Stepanyan, K., Mather, R., \& Dalrymple, R. (2014). Culture, role and group work: A social network analysis perspective on an online collaborative course. British Journal of Educational Technology, 45(4), 676-693.

Thibaut, J. W., \& Kelley, H. H. (1959). The Social Psychology of Groups. New York: John Wiley \& Sons, Inc.

Teo, T., \& Wong, S. L. (2013). Modeling key drivers of e-learning satisfaction among student teachers. Journal of Educational Computing Research, 48(1), 71-95.

Terenzini, P. T., Cabrera, A. F., Colbeck, C. L., Parente, J. M., \& Bjorklund, S. A. (2001). Collaborative Learning vs. Lecture/Discussion: Students’ Reported Learning Gains. Journal of Engineering Education, 90(1), 123-130.

Van den Bossche, P., Gijselaers, W. H., Segers, M., \& Kirschner, P. A. (2006). Social and cognitive factors driving teamwork in collaborative learning environments: Team learning beliefs and behaviors. Small Group Research, 37(5), 490-521.

van Staalduinen, J.P. \& de Freitas, S. (2011). A game-based learning framework: Linking game design and learning. In M. S. Khyne (Ed.). Learning to Play: Exploring the future of education with video games, 1-37. New York: Peter Lang. 
Vos, L., \& Brennan, R. (2010). Marketing simulation games: student and lecturer perspectives. Marketing Intelligence \& Planning, 28(7), 882-897.

Vygotsky, L. S. (1978). Mind in Society: The development of higher psychological processes. Translated by A.R. Luria, M.M. Lopez-Morillas, Michael Cole and J. Wertsch. Cambridge, MA: Harvard University Press.

Xu, Y., \& Yang, Y. (2010). Student learning in business simulation: An empirical investigation. Journal of Education for Business, 85(4), 223-228.

Zhu, C. (2012). Student satisfaction, performance, and knowledge construction in online collaborative learning. Journal of Educational Technology \& Society, 15(1), 127-136. 
Appendix 1: Key quantitative measures

\begin{tabular}{|c|c|c|c|}
\hline Construct & Item name & Statement & $\begin{array}{l}\text { Retained } \\
\text { Items }\end{array}$ \\
\hline \multirow[t]{17}{*}{ Teamwork } & Teamwork1 & It was easy for the team to agree on important decisions & \\
\hline & Teamwork2 & $\begin{array}{l}\text { Key decisions about our company were made by the entire } \\
\text { team }\end{array}$ & $\mathrm{E}, \mathrm{C}$ \\
\hline & Teamwork3 & I was comfortable sharing my ideas with my team & \\
\hline & Teamwork4 & $\begin{array}{l}\text { Most of the time, members of my team asked each other for } \\
\text { feedback on their work }\end{array}$ & $\mathrm{E}, \mathrm{C}$ \\
\hline & Teamwork5 & Team members acknowledged the points of view of others & $\mathrm{E}, \mathrm{C}$ \\
\hline & Teamwork6 & There was a team leader who guided the simulation & \\
\hline & Teamwork7 & $\begin{array}{l}\text { The contributions of other team members assisted my } \\
\text { understanding of the simulation }\end{array}$ & $\mathrm{E}, \mathrm{C}$ \\
\hline & Teamwork8 & My team had regular meetings to evaluate our performance & $\mathrm{E}$ \\
\hline & Teamwork9 & My team performed well in the simulation & \\
\hline & Teamwork10 & My team was dedicated to the task & $\mathrm{E}, \mathrm{C}$ \\
\hline & Teamwork11 & My team worked well together & $\mathrm{E}, \mathrm{C}$ \\
\hline & Teamwork12 & My team actively exchanged ideas using online tools & $\mathrm{E}, \mathrm{C}$ \\
\hline & Teamwork13 & $\begin{array}{l}\text { The unique skills and talents of each team member was fully } \\
\text { valued and utilized }\end{array}$ & $\mathrm{E}, \mathrm{C}$ \\
\hline & Teamwork14 & $\begin{array}{l}\text { My team interactions helped me to understand other points of } \\
\text { view }\end{array}$ & $\mathrm{E}, \mathrm{C}$ \\
\hline & Teamwork15 & Working as a team allowed me to work smarter, not harder & $\mathrm{E}, \mathrm{C}$ \\
\hline & Teamwork16 & $\begin{array}{l}\text { I was able to learn new skills and knowledge from other } \\
\text { members in my team }\end{array}$ & $\mathrm{E}, \mathrm{C}$ \\
\hline & Teamwork17 & $\begin{array}{l}\text { Competition between teams motivated me to spend more time } \\
\text { on the simulation }\end{array}$ & \\
\hline \multirow[t]{14}{*}{ Learning } & Outcomes1 & Problem-solving skills & $\mathrm{E}, \mathrm{C}$ \\
\hline & Outcomes2 & Planning skills & $\mathrm{E}$ \\
\hline & Outcomes3 & Understanding of finance & $\mathrm{E}, \mathrm{C}$ \\
\hline & Outcomes4 & Understanding of marketing & $\mathrm{E}$ \\
\hline & Outcomes5 & Understanding of staffing & $\mathrm{E}, \mathrm{C}$ \\
\hline & Outcomes6 & Understanding of operations & $\mathrm{E}, \mathrm{C}$ \\
\hline & Outcomes 7 & Understanding of strategic management & $\mathrm{E}, \mathrm{C}$ \\
\hline & Outcomes8 & $\begin{array}{l}\text { Understanding of how the different departments of an } \\
\text { organization interact with each other }\end{array}$ & \\
\hline & Outcomes9 & $\begin{array}{l}\text { Understanding of 'real world' problems faced by } \\
\text { organizations }\end{array}$ & \\
\hline & Outcomes10 & Knowledge of key business terms, concepts and conventions & \\
\hline & Outcomes11 & Ability to apply my knowledge to a business & \\
\hline & Outcomes12 & Ability to analyze data & \\
\hline & Outcomes13 & Ability to evaluate problems and make decisions & \\
\hline & Outcomes14 & Ability to create new ideas or plans & \\
\hline \multirow[t]{4}{*}{ Satisfaction } & Enjoy1 & The simulation was challenging & \\
\hline & Enjoy2 & I enjoyed learning with the simulation & $\mathrm{E}, \mathrm{C}$ \\
\hline & Enjoy3 & The simulation made the course more interesting & $\mathrm{E}, \mathrm{C}$ \\
\hline & Enjoy4 & $\begin{array}{l}\text { The simulation allowed me to build on knowledge gained } \\
\text { from previous courses }\end{array}$ & \\
\hline
\end{tabular}




\begin{tabular}{|l|l|l|c|}
\hline & Enjoy5 & $\begin{array}{l}\text { The simulation allowed me to learn from my mistakes through } \\
\text { trial and error }\end{array}$ & \\
\hline & Enjoy6 & I feel I am more 'work ready' after using the simulation & E \\
\hline & Enjoy7 & $\begin{array}{l}\text { The skills and knowledge learnt during the simulation will be } \\
\text { useful for my future career }\end{array}$ & E, C \\
& Enjoy8 & $\begin{array}{l}\text { I am satisfied with the online software application used for the } \\
\text { simulation }\end{array}$ & E, C \\
\hline & Enjoy9 & Overall, I learned a lot from the simulation & E, C \\
\hline & Enjoy10 & Overall, I am satisfied with the simulation as a learning tool & E, C \\
\hline & Enjoy11 & Overall, the simulation has met my expectations & E, C \\
\hline
\end{tabular}

Note: $\mathrm{E}=$ retained after Exploratory Factor Analysis; $\mathrm{C}=$ retained after Confirmatory Factor Analysis. 